UNTAG Law Review (ULREV)

Volume 3, Issue 2, November 2019, PP 164-177

ISSN 2549-4910 (online) \& ISSN 2579-5279 (print)

http://jurnal.untagsmg.ac.id/indeks.php/ulrev/indeks

www.fakhukum.untagsmg.ac.id

\title{
CONCEPT OF APPLICATION OF WORKERS 'CONSTITUTIONAL RIGHTS JUSTICE OUTSOURCING
}

\author{
Mashari \\ Lecture Fakulty of Law Universitas 17 Agustus 1945 Semarang \\ Email : mmashary@gmail.com
}

\begin{abstract}
The application of the constitutional rights of outsourced workers must be equal to the position of every citizen in the law guaranteed by Article 27 paragraph (1) and 28D paragraph (1) of the 1945 Constitution. Equality granted equally between workers and employers gives freedom to the parties. In Article 28E paragraph (2) of the 1945 Constitution regulates that every person has the right to freedom to believe in beliefs, express their thoughts and attitudes, in accordance with his conscience. Regulations on the rights of workers and employers have an equal position in conveying their wishes and thoughts regarding an agreement between the parties, free from pressure or coercion from any party. The application of the constitutional rights of outsourced workers in the 1945 Constitution as a social constitution is a source of normative references, both in legal and ethical contexts. The 1945 Constitution as a source of law and at the same time a source of ethics and morals can be functioned as a source of references and guidelines for ideal behavior in the context of state activities and community activities. The Government of Indonesia is to protect the whole nation and all Indonesian blood. Fulfillment of justice and welfare improvement as a protection for workers is carried out in the form of labor social security, with the principle of kinship and mutual cooperation in line with the soul and spirit of the Pancasila and the 1945 Constitution. outsourcing workers with other workers as long as the workers do the same work.
\end{abstract}

Keywords : Constitutional Rights, Justice, Outsourcing

\section{INTRODUCTION}

Indonesia as a state of law, which in the implementation of state power is carried out under the rule of law. The logical consequence, the entire system of administration of state administration must be based on the constitution. ${ }^{1}$ Every implementation of state or

1 Moh. Mahfud MD, 2007, Debate on Constitutional Law Post Constitutional Amendment, LP3ES, Jakarta, p. 57. 
government power is always built by and based on the principles and provisions of the constitution.

The Indonesian Constitution states that the human rights of all citizens must not be violated and must be fulfilled. The provisions of Article 1 paragraph (1) of Law Number 39 of 1999 concerning Human Rights, which basically says that human rights are rights that are inherent and inherent in every person as God's creatures. As rights inherent in every human person, human rights are gifts that must be respected, upheld, guaranteed and protected by the state, law and government, for the glory and protection of human dignity.

Jimly Asshiddiqie's view, ${ }^{2}$ not all constitutional rights are similar to human rights, because there are some constitutional rights of citizens who are not included in the definition of human rights. Constitutional rights can be interpreted as human rights that have been expressly stated in the 1945 Constitution, so that they are officially constitutional rights of every Indonesian citizen. This is what distinguishes constitutional rights from legal rights (legal rights) guaranteed and regulated in the laws and regulations under it (subordinate legislation). ${ }^{3}$

The constitution is usually interpreted as the basic law of a country that regulates the political system, among others by establishing the basic institutions of government, as well as the authority and relations of each institution. Every regulation made or state action must not contradict the constitution. In this sense, it can be said that the constitution is an affirmation of the rule of law.

In the basic laws in all countries basically have aspects of human rights. These rights such as freedom of speech, freedom of expression of thoughts, attitudes and opinions, the right and freedom of association and assembly and the right to work and determine work. In the field of labor, an adequate livelihood and the right to work as stipulated in Article 27 paragraph (2), 28D paragraph (2), and 28E paragraph (1) of the 1945 Constitution are human rights guaranteed by the government for all its citizens. In creating a decent life there must be a guarantee of fair legal justice.

The concept of social justice is a knot of all dimensions and aspects of the humanitarian idea of sadness. In the concept of social justice contained recognition of human dignity that has the same rights that are fundamental. Although social justice is different from legal justice which is usually imposed through a legal process, social justice is ultimately the result of a combination of legal justice and economic justice that is in it.

2 Jimly Asshiddiqie, 2009, The Constitutional Law Tweet \& Maxwell Asia, Malaysia, p. 494

3 Jimly Asshiddiqie, 2006, Introduction to the Law of State Administration Volume 2, Constitution Press, Jakarta, p. 134. 
This study aims to find the concept of applying the constitutional rights of outsourced workers employed under PKWT to have the same constitutional rights as other PKWTT workers. In addition, Law Number 13 Year 2003 regarding Manpower also stipulates that each worker is not distinguished by the status or type of contract in his employment relationship. The application of constitutional rights must be a certainty for every worker, including outsourced workers who have not received social justice. Outsiders must instead understand and implement the rights and obligations of each party as compliance with the state.

\section{Problem Formulation}

Based on the preliminary description above, the writer can formulate the problem as follows:

1. Why is there a problem with the application of the constitutional rights of outsourced workers in the 1945 Constitution?

2. What is the concept of applying the constitutional rights of outsourced workers in the 1945 Constitution that is just?

\section{Research methods}

The research method used is an empirical juridical research method. Juridical research is based on a normative approach that analyzes various laws and regulations in the field of labor that has a relationship with the constitutional rights of outsourced workers in the 1945 Constitution that is just.

In empirical research it is used to analyze the law not merely as a set of normative laws and regulations, but the law here is seen as a symptom of community behavior and patterning in people's lives, always interacting and relating to social aspects such as politics, economic, social and cultural.

\section{Discussion}

\section{Implementation of the Constitutional Rights of Outsourcing Workers in the $\mathbf{1 9 4 5}$ Constitution}

\section{a. The Constitutional Rights of Outsourcing Workers in Indonesia}

The term outsourcing is literally interpreted as outsourcing or delegating a business process to a third party. Outsourcing with the intention of showing the transfer or utilization of labor by employers from one company to another company. ${ }^{4}$ Outsourcing can be interpreted as the transfer or delegation of some business processes to a service provider, which carries out

4 Rina Herawati, 2010, Contracts and Outsourcing Must Be More Cautious, Akatiga da FES Foundation, Bandung, p. 2 
administrative and management processes based on criteria agreed upon by the parties.

Understanding of constitutional rights for outsourced workers was originally created as a solution to overcome high unemployment. The Universal Declaration of Human Rights states expressly that "everyone has the right to work". The right to work is considered a complex right inside the arrangement is towards a social security scheme. The natural "right to work" is a moral challenge for the economic system, not just a right that is offended by understanding and law enforcement. ${ }^{5}$

According to C. Wilfred Jenks, ${ }^{6}$ the effectiveness of the "right to work" depends partly on a country's economic policies and partly depends on employment services, responsible training facilities in a dynamic economy, and from positive policies designed to facilitate changes in employment. to other jobs because of the situation that is needed as a contribution to rewarding and maintaining full employment and full development that is useful for and utilization of sources of productivity. ${ }^{7}$

The effectiveness of "the right to work" depends partly on economic policy and partly on the provision of employment services and training facilities which recognize the need, in the dynamic economy of a positive policy designed to facilitate changes from one employment to another as conditions require as a contribution to the achievement and maintenance of full employment and the fullest development and use of productive resources.

The right to work in the 1945 Constitution, contained in Article 28D paragraph (2) which states "every person has the right to work and get fair and proper remuneration and treatment in an employment relationship." With the right of everyone to work as a constitutional right, all Indonesian citizens have guarantees for work that can be realized by government systems or policies. This article can also be categorized into Economic, Social and Cultural rights, namely the types of human rights related to material, social and cultural welfare. ${ }^{8}$

In this context it means that the government has an obligation to provide employment for every citizen so they can work.

In Article 28D paragraph (2) of the 1945 Constitution, namely "... and receive compensation and fair and proper treatment in employment relations" implies that every worker must get a reward. Rewards that is in the form of wages in accordance with the work done. In addition, workers must also be treated fairly and appropriately, regardless of the type of work

5 Articles, Outsourced Seen From the Perspective of Employer Companies, http: // www. apindo.or.id

6 C. Wilfred Jenks, 1960, Human Rights and International Labor Standards, Stevens \& Sons Limited, London, p. 120 .

7 C. Wilfred Jenks, Ibid., P. 121.

8 Triana Sofiani, Constitutional Rights of Women Workers in the State Welfare Law Frame in Indonesia, (Muwazah Journal of Gender Studies, Volume 6, No. 1, 2004), p. 103. 
relationship. Outsourcing workers, both those who have a PKWTT or PKWT work relationship, have the right to be treated equally and fairly by both outsourcing companies (vendors) and by employer (user) companies.

The right to be treated equally and equally is also listed in Article 5 and Article 6 of Law Number 13 Year 2003 concerning Manpower. Similar rules are also contained in Article 38 of Law Number 39 Year 1999 concerning Human Rights stating that every person, both men and women who do the same, equal, equal or similar work, is entitled to the same salary and terms of employment agreement. The International Convention which has been ratified by Indonesia, namely the ILO C100 Convention of 1951, also sets the same wage standards and principles for male and female workers for work of equal value. In addition, ILO Convention No. 111 of 1958 which had also been ratified by Indonesia through Law Number 20 of 1999 emphasized the prohibition of discrimination in the workplace, against differences in sex, ethnicity, skin color, religion and political flow.

The Indonesian Constitution stipulates that every citizen has the right to work and a decent living for humanity as stated in Article 27 paragraph (2) of the 1945 Constitution, which reads "Every citizen has the right to work and a decent living for humanity." The article has meaning that every citizen is guaranteed to get a job with a decent income, including housing / means of living as a decent place for humanity by the state. The state has the obligation and responsibility to provide jobs with decent income and decent means of livelihood.

According to Jimly Asshiddiqie, legal justice and economic justice must produce the final result in the realization of social justice for all, which contains the understanding that the state c.q government responsible for ensuring the basic quality of life for all citizens. In the context of wage protection and to fulfill decent livelihoods, the government has established policies or provisions regarding wages and each employer is required to arrange wage structures and scales by taking into account occupational classes, years of service, education and competence and conducting regular wage reviews. ${ }^{9}$ The constitution views the employment relationship between employers as employers and workers as workers being at a more essential issue, namely protection of workers' rights. The protection of workers' rights to obtain a decent living and fair treatment in work relationships is expressly regulated in Article Law No. 13 of 2003 concerning Manpower states that "Every worker / laborer has the right to have the same opportunity without discrimination to obtain employment" and Article 6 which states "Every worker has the right to receive the same treatment without discrimination from employers. "

\section{b. Implementation of the Position of Outsourcing Workers in the 1945 Constitution}

In employment relations, the interests of employers, government, and workers, have a

9 Payaman J. Simanjuntak, New Law on Employment, p. 32. 
relationship between one another. However, these interests can be attracted to one another, so it is not easy to achieve justice. Referring to John Rawls's opinion, justice can only be achieved when the distribution of primary goods has been distributed equally to all citizens. ${ }^{10}$ In guaranteeing this, the government and the legislature must make rules that guarantee the implementation of the rights of workers and employers.

John Rawls's view, ${ }^{11}$, that justice is not one-sided, equal and impartial can be achieved one of them by guaranteeing freedom of choice. In Indonesia, the freedom to choose, especially in the field of labor has been mandated by the Constitution 1945, listed in Article 28E paragraph (1). The article states that "Every person is free to embrace religion and worship according to his religion, choose education and teaching, choose work, choose citizenship, choose a place to live in the territory of the country and leave it, and the right to return."

The Indonesian Constitution guarantees legal certainty, equal position and equal treatment before the law as referred to in Article 27 paragraph (1) and 28D paragraph (1) of the 1945 Constitution, which regulates: "All citizens are equal in law and government and must uphold the law and government with no exception "and" every person has the right to recognition, guarantees, protection and certainty of law which is fair and equal treatment before the law. "

The principle of equality before the law also applies to outsourcing work systems. Regulations and policies, the government plays an important role in distributing rights and obligations equally between employer companies (users), outsourcing companies (vendors), and workers, in such a way as to create justice for all parties.

Everyone is free to choose work, outsourcing or non-outsourcing work. Freedom of choice in outsourcing, meaning that there is no coercion of individuals in carrying out work. In other words the freedom to choose outsourcing work is a constitutional right of every citizen that has been guaranteed by the 1945 Constitution. An important change through the second amendment of the 1945 Constitution is the affirmation of human rights, which is included in a separate chapter, namely Chapter XA. The ten articles concerning human rights are a reflection that the state of Indonesia is a state of law. ${ }^{12}$ Every policy, the government must pay attention to the equality of the position of every citizen in the law that has been guaranteed by Article 27 paragraph (1) and 28D paragraph (1) of the 1945 Constitution. Equality provided equally between workers and employers gives freedom to the parties to determine the contents, parties and objects to be promised. In Article 28E paragraph (2) of the 1945 Constitution regulates that every person has the right to freedom of belief, to express his thoughts and attitudes, in accordance with his conscience, including pouring them into a statement and agreement.

10 John Rawls, A Theory of Justice, revised edition, p. 79

11 John Rawls, Ibid., P. 81.

12 Majda El-Muhtaj, 2007, Human Rights in Indonesian Consultations, Kencana Prenada Media Group, Jakarta, p. 112. 


\section{The Concept of Applying the Constitutional Rights of Outsourcing Workers in the 1945 Constitution}

\section{a. Justice for Outsourcing Workers in the Perspective of the Constitution}

In John Rawls's theory of justice, ${ }^{13}$ it can be interpreted that the rights of workers and employers can only be implemented if there is a guarantee of fair equality of opportunity and freedom of choice referred to in Article 27 paragraph (1) and 28D paragraph (1) of the 1945 Constitution. Guarantees for the status of workers and employers are reflected in the regulations and policies issued by the government by taking into account the equal position in the law as equal. This provides freedom for workers and employers in making employment contracts to provide legal certainty between the rights and obligations of each party guaranteed in Article 28E paragraph (2) of the 1945 Constitution.

According to Jimly Asshiddiqie, ${ }^{14}$ the idea of justice contains many aspects and dimensions, namely legal justice, economic justice, political justice, and social justice. Social justice is not synonymous with economic justice or legal justice. Social justice is also not the same as the values of justice envisioned in the philosophy of life that is commonly developed by philosophers. Thoughts and dreams about justice are actual in real life reflected in the structure of collective life in society. All ideas about legal justice and economic justice are real social justice.

Social Justice is formulated as the fifth precepts in Pancasila. But the content of its meaning becomes more pronounced when directly reading from the formulation of Paragraph IV of the Preamble of the 1945 Constitution, in the first, second, third and fourth precepts are statically formulated as the basic objects of the state. Social justice is formulated with active sentences. In paragraph IV of the Preamble of the 1945 Constitution it is written:

Then than that to form an Indonesian Government that protects all Indonesian people and all of Indonesia's blood and to promote public welfare, educate the nation's life, and participate in carrying out world order based on independence, eternal peace and social justice, the Indonesian National Independence was drafted. in a Constitution of the Republic of Indonesia, which is formed in the composition of the Republic of Indonesia which is sovereignty of the people based on the Almighty God, Humanity that is just and civilized, Indonesian Unity and Popularism led by wisdom in Consultative / Representative, and by realizing a social justice for all Indonesian people.

Based on the above it can be formulated, First, social justice as "a" that is concrete, not just

13 John Rawls, Op. Cit, p. 53.

14 Jimly Asshiddiqie, Constitutional Message of Social Justice, (Journal of the Constitution, Malang, 12 April 2011), p. 1 
abstract-philosophical which is not merely used as political jargon without meaning. Second, social justice is not only a subject that must be realized dynamically in a form of social justice for all Indonesian people.

In the 1945 Constitution as a social constitution it is a source of normative references, both in legal and ethical contexts. The 1945 Constitution as a source of law and at the same time a source of ethics and morals can be functioned as a source of references and guidelines for ideal behavior in the context of state activities and community activities. In the context of state activities, the 1945 Constitution is referred to as a political constitution, whereas in the context of social activities it is called a social constitution. ${ }^{15}$

Fulfillment of justice and welfare improvement as a protection for workers is carried out in the form of labor social security, with the principle of kinship and mutual cooperation in line with the soul and spirit of Pancasila and the 1945 Constitution. The form of protection of labor as part of the population and the community must be guaranteed by every employer or company. ${ }^{16}$ Referring to Kranenburg's opinion, the rule of law in carrying out its duties must be based on fair and equitable justice. Kranenburg's opinion is in line with the tasks of the Government of Indonesia which is reflected in the body of the 1945 Constitution Article 1 paragraph (3) which states that the State of Indonesia is a state of law. ${ }^{17}$

The Constitutional Court has several times been amended to amend Law No. 13 of 2003 concerning Labor. Some articles in the law are even considered to be contrary to the 1945 Constitution. Like Article 158 of Law Number 13 Year 2003 concerning Manpower which has been declared contrary to the 1945 Constitution and does not have binding legal force. As previously explained that in Article 5 and Article 6 of Law Number 13 Year 2003 concerning Manpower, it states the guarantee of protection for all citizens without discrimination. Workers' protection is the granting of rights and obligations as well as the protection of each workforce and guaranteeing equal opportunities to obtain decent work and livelihoods regardless of sex, ethnicity, race, religion, and political affiliation. ${ }^{18}$

\section{b. The Application of the Constitutional Rights of Outsourcing Workers in the 1945 Constitution}

Each country is part of the international world, which is even now incorporated in the United Nations (UN) or the United Nations. Likewise with Indonesia as a member of the UN can not be separated from UN sovereignty and international regulations. A country to fulfill its

15 Jimly Asshiddiqie, Ibid., P. 61.

16 Indonesia, Pancasila, Fifth Sila, "Social justice for all Indonesian people."

17 Moh. Mahfud MD, 2000, Principles and Structure of Indonesian State Administration, Revised Edition, Publisher Renaka Cipta, Jakarta, p. 64.

18 Abdul Hakim, 2003, Introduction to Labor Law Based on Law No. 13 of 2003, Citra Aditya Bakti, Bandung, p. 60 
domestic needs often needs help, even forcing a country to cooperate with other countries as part of the international world. ${ }^{19}$

According to Yusril Ihza Mahendra, ${ }^{20}$ that the constitution was formed with the intention that the state administrators have a clear direction in carrying out their power. The constitution functions to organize power so that it cannot be used forcefully and arbitrarily. ${ }^{21}$ The constitution must function as a leading constitution so that it is not only used as a symbol of a state that has no teeth at all, which is caused by a number of laws that are not in line with the substance of the constitution, or are interpreted based on momentary interests to maintain power. $^{22}$

International law also affects the regulations of a country, even the constitution in a country. For example the Universal Declaration of Human Rights 1948 (DUHAM), adopted in the Constitution of the Republic of Indonesia (RIS) and the Provisional Constitution (UUDS) 1950 which then through the Presidential Decree issued by President Soekarno returned the constitution to the 1945 Constitution, the 1945 Constitution before the amendment indeed only contain limited human rights. In the reformation era, the UDHR continues to exert influence on the amendments to the 1945 Constitution which include more complete regulation of human rights. ${ }^{23}$

The ILO was established to improve the protection of workers, working conditions and the welfare of the working community in each country in order to create justice and humanity, and to guarantee world peace. ${ }^{24}$ One of the functions of the ILO is to develop standards in the form of conventions and recommendations. The Convention contains labor provisions that need to be ratified as evidence of official commitments and obligations for the country concerned to implement them. The recommendations contain policy guidelines, arrangements and implementation of labor provisions which can be taken in whole or in part by each country without going through ratification.

19 Firdaus, International Legal Position in Indonesia's National Legislative System, Journal of the Fiat Justitia Hukum, Volume 5, No. 1, January-March 2014, p. 37.

20 Yusril Ihza Mahendra, 1996, Dynamics of the Indonesian State Administration, Actual Compilation of the Constitutional Problems of the House of Representatives and Party Systems, Gema Insani Press, Jakarta, p. 46.

21 Taufiqurrohman Syahuri, 2004, Constitutional Law Process and Procedure for Changing the Constitution in Indonesia 1945-2002, Ghalia Indonesia, Jakarta, p. 37.

22 Marwan Mas, Deciphering the Decision on Cancellation of Law Number 45 Year 1999, Journal of the Constitution, Volume 1 No. 2, December 2004, p. 17.

23 R. Herlambang Perdana Wiratraman, Citizens' Constitutional Rights After Amendments to the 1945 Constitution: Concepts, Arrangements, and Dynamics of Implementation, Panta Rei Law Journal - Jakarta Consortium for National Law Reform, Volume 1, December 2007, p. 5

24 Payaman J. Simanjuntak, 2011, Industrial Relations Management, Publisher Institute of the Faculty of Economics, University of Indonesia, Jakarta, p. 251. 
In creating social justice in the international labor field, on 11 April 1919 the International Labor Organization (ILO) was established based on the Versailles Peace Conference. The ILO functions as the international labor standards maker, runs operational programs, and manpower training. ${ }^{25}$ The rules issued by the ILO are seen or enforced as International Labor Standards.

Indonesia has only ratified 18 ILO Conventions, ${ }^{26}$ where Indonesia has bound consequences to implement the provisions in the ILO Conventions. Specifically for the ILO Basic Conventions, ILO member countries (including Indonesia) have an obligation to respect, promote and implement the principles contained in the conventions of the ILO regardless of whether the country has ratified them or not. This is based on the ILO Declaration on Fundamental Principles and Rights at work, which was accepted and approved by the International Labor Conference in its 86th session in June 1998.

The problem that is often faced by each country is the gap and differences in treatment between men and women, including in the world of work. The gap is not only in the form of differences in opportunities for women to work in what is often referred to as "men's work", but the discrimination also concerns the wage gap between men and women. The gap in male labor is greater than female labor, so the work that can be done by a man is more and more efficient than what is done by women. The various obstacles that occur can lead to violations of basic rights and hamper women's opportunities and in turn will harm society and the economy of a country, given the loss of large contributions that women can make through the workplace. ${ }^{27}$. In Article 2 the ILO Convention explains how the attitude of member countries to apply remuneration, namely:

a. In a manner that is in accordance with the applicable methods for determining the value of wages, each member must promote and in that way, ensure the implementation of the principle of equal pay for male and female workers for work of equal value to all workers;

b. This principle can be implemented; (a) with national laws or regulations; (b) by the wage setting body established according to applicable regulations or recognized as being legal; (c) through collective work agreements between employers and workers; or (d) by combining these methods.

Equality in wages has been guaranteed by Article 28D paragraph (2) of the 1945 Constitution which states that every person has the right to get a decent and fair wage. Discrimination in

25 Dede Agus, Position of the ILO Convention as the Source of Indonesian Labor / Labor Law, Journal of International Law, Volume 1, No. 1, July 2013, p. 7-8.

26 Asia Pacific Decend Work, 2013

27 International Labor Office, 2006, ILO Conventions on Gender Equality in the World of Work, ILO Jakarta Office, Jakarta, pp. Iii. 
respect of wages based on sex is an unfair act. In reality, women workers are a group that usually receives lower wages than men.

\section{Conclusions}

Based on the description of the discussion above, the writer can conclude his research objectives as follows:

a. The application of the constitutional rights of outsourced workers must be equal to the position of every citizen in the law guaranteed by Article 27 paragraph (1) and 28D paragraph (1) of the 1945 Constitution. Equality granted equally between workers and employers gives freedom to the parties. In Article 28E paragraph (2) of the 1945 Constitution regulates that every person has the right to freedom to believe in beliefs, express their thoughts and attitudes, in accordance with his conscience. Regulations on the rights of workers and employers have an equal position in conveying their wishes and thoughts regarding an agreement between the parties, free from pressure or coercion from any party.

b. The application of the constitutional rights of outsourced workers in the 1945 Constitution as a social constitution is a source of normative references, both in legal and ethical contexts. The 1945 Constitution as a source of law and at the same time a source of ethics and morals can be functioned as a source of references and guidelines for ideal behavior in the context of state activities and community activities. The Government of Indonesia is to protect the whole nation and all Indonesian blood. Fulfillment of justice and welfare improvement as a protection for workers is carried out in the form of labor social security, with the principle of kinship and mutual cooperation in line with the soul and spirit of the Pancasila and the 1945 Constitution. outsourcing workers with other workers as long as the workers do the same work.

\section{Suggestions}

a. State administrators should provide clear direction in carrying out their power, based on the constitution so that they can provide protection for workers in the form of labor social security.

b. Social constitutions should be a source of normative references, both in the legal and ethical contexts, so that they become guidelines for ideal behavior in the context of state and community activities.

\section{REFERENCES}

Abdul Hakim, 2003, Introduction to Labor Law Based on Law No. 13 of 2003, Citra Aditya Bakti, Bandung. 
Asia Pacific Decend Work Decade 2006-2015, 2013, International Labor Organization, Right to Decent Work for Persons with Disabilities, ILO, Jakarta.

C. Wilfred Jenks, 1960, Human Rights and International Labor Standards, Stevens \& Sons Limited, London.

Jimly Asshiddiqie, 2009, The Constitutional Law, Sweet \& Maxwell Asia, Malaysia.

-, 2006, Introduction to the Law of State Administration Volume 2, Constitution Press, Jakarta.

John Rawls, A Theory of Justice, Revised Edition.

International Labor Office, 2006, ILO Conventions on Gender Equality in the World of Work, ILO Jakarta Office, Jakarta.

Majda El-Muhtaj, 2007, Human Rights in Indonesian Consultation, Kencana Prenada Media Group, Jakarta.

Ministry of Labor, 2003, Invalids and Social Affairs (MOLISA), Research Center for Female Labor (RCFL) and F. Howell: Equality, Labor and Social Protection for Women and Men in the Formal and Informal Economy in Vietnam, ILO, Hanoi.

Moh. Mahfud MD, 2000, Principles and Indonesian Administrative Structure (Revised Edition), Publisher Renaka Cipta, Jakarta.

LP3ES, Jakarta.

International Labor Organization, 2008, Informal Economy: Transition to Formalization, Working Papers, ILO, Jakarta.

Payaman J. Simanjuntak, 2011, Industrial Relations Management, Publisher Institute of the Faculty of Economics, University of Indonesia, Jakarta.

, New Law on Manpower.

Rina Herawati, 2010, Contracts and Outsourcing Must Be Beware, Akatiga da FES Foundation, Bandung.

Taufiqurrohman Syahuri, 2004, Constitutional Law Process and Procedure for Changing the Constitution in Indonesia 1945-2002, Ghalia Indonesia, Jakarta.

Yusril Ihza Mahendra, 1996, The Dynamics of Indonesia's State Administration, Actual Compilation of the Constitutional Problems of the House of Representatives and Party System, Gema Insani Press, Jakarta. 


\section{Legislation:}

1945 Constitution of the Republic of Indonesia Law Number 13 of 2003 concerning Manpower Law Number 39 of 1999 concerning Human Rights

Convention International Labor Organization No. 100, 1951 in Geneva ("ILO C100") Article 3, regulates as follows: (1) Where such action will assist In giving effect to the provisions of this Convention measures shall be taken to promote the objective appraisal of jobs on the basis of the work to be performed (2) The methods to be followed in this appraisal may be decided upon by the men and women workers for work of equal value. See International Labor Organization Convention No. 100

Dede Agus, Position of the ILO Convention as the Source of Indonesian Labor / Labor Law, Journal of International Law, Volume 1, No. 1, July 2013.

Ministry of Manpower and Transmigration, Guide: Equal Opportunities and Treatment in Employment in Indonesia.

Firdaus, International Legal Position in Indonesia's National Legislative System, Journal of the Fiat Justitia Hukum, Volume 5, No. 1, January-March 2014.

Firdaus, International Legal Position in Indonesia's National Legislative System, Journal of the Fiat Justitia Hukum, Volume 5, No. 1, January-March 2014.

Jimly Asshiddiqie, Constitutional Message Social Justice, Constitutional Journal, Malang, April 12, 2011.

Indonesia, Pancasila, Fifth Sila "Social justice for all Indonesian people."

International Labor Office, 2006, ILO Conventions on Gender Equality in the World of Work, ILO Jakarta Office, Jakarta.

Marwan Mas, 2004, Deciphering Decision on Cancellation of Law Number 45 Year 1999, Journal of the Constitution, Volume 1 No. 2, December.

R. Herlambang Perdana Wiratraman, Citizens' Constitutional Rights After Amendments to the 1945 Constitution: Concepts, Arrangements, and Dynamics of Implementation, Panta Rei-Jakarta Legal Journal Consortium for National Law Reform, Volume 1, December 2007.

Triana Sofiani, 2004, Constitutional Rights of Women Workers in the Welfare Legal Framework in Indonesia, Muwazah Journal of Gender Studies, Volume 6, No. 1

Articles, Outsourced Seen From the Perspective of Employer Companies, http: // www. apindo.or.id 
ILO, "ILO Conventions on Gender Equality in the World of Work", Presentation 111 Discrimination (In Employment and Position of the 1958 Convention), p. 49, http://www.ilo.org/wcmsp5/groups/public/@asia/@ro-bangkok/@ilojakarta/documents/publication/wcms_122045.pdf,4 accessed in October 2016.

Supreme Court, "Curriculum for Industrial Relations Court Judges", p. 208, http://www.ilo.org/wcmsp5/groups/public/---asia/---ro-bangkok/---ilojakarta/document/publication/wcms_235223.'pdf, accessed on 4 October 2006. 